\title{
東北地方太平洋沖地震津波による漁港海岸保全施設の被災要因の検討
}

\section{Research on Damage Factors of Coastal Conservation Facilities due Tohoku Earthquake Tsunami}

\author{
加藤広之 $^{1} \cdot$ 林 $_{\text {健太郎 }}^{2} \cdot$ 中村 隆 $^{3} \cdot$ 中山哲嚴 ${ }^{4} \cdot$ 八木 宏 $^{5}$
}

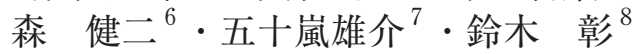

\section{Hiroyuki KATO, Kentaro HAYASHI, Takashi NAKAMURA, Akiyoshi NAKAYAMA, Hiroshi YAGI Kenji MORI, Yuusuke IGARASHI and Akira SUZUKI}

\begin{abstract}
In this study, simple field surveys were conducted at 29 fishing ports whose shore protection facilities had been damaged by the Tohoku Earthquake Tsunami occurred on March 11, 2011. Among the sites, 10 fishing ports were selected in order to investigate the characteristic of damage mechanism by conducting detailed field surveys. Based on the detailed field surveys, tsunami numerical simulations with non-linear long wave equation or CADMAS-SURF are implemented to investigate damage mechanism of the port facilities.
\end{abstract}

\section{1.はじめに}

2011 年3月 11 日に発生した東北地方太平洋沖津波によ り, 東北地方沿岸の漁港海岸施設は甚大な被害を受けた. 海岸保全施設の被害は同一海岸においても被害の有無, 被害の程度が異なっていた。

岩手・宮城・福島県の海岸保全施設を有する29漁港に おいて, 海岸保全施設被害の概況を踏査し, その中から 被災規模が大きく, 被災施設および被災状況に特徵のあ る 10 漁港海岸について被災状況を詳細に調査した.さら に, 越喜来漁港, 宿漁港について, 津波遡上シミュレー ションおよびキャドマスサーフにより被災の有無, 被災 状況の違いが生じた要因を検討するとともに, 詳細調査 結果と比較し, 漁港海岸における海岸保全施設の被災义 カニズムについて考察した.

\section{2. 被害調査}

\section{（1）被災概況調查}

岩手・宮城・福島県の漁港海岸を有する全 140 漁港の うち，1）海岸保全施設の構造，2）被災形態と被災規模, 3）津波高（外力の大きさ）, 4）地理的特性（外洋 - 内 湾など)，5）背後地の被害状況を勘案し，表-1に示す岩

\begin{tabular}{|c|c|c|c|}
\hline 1 & & & (財) 漁港漁場漁村技術研究所 研究主幹 \\
\hline & 正会員 & 修(工) & $\begin{array}{l}\text { (株) アルファ水工コンサルタンツ } \\
\text { 東京本部 チームリーダー }\end{array}$ \\
\hline & & & (財) 漁港漁場漁村技術研究所 部長 \\
\hline & 正会員 & 修(工) & $\begin{array}{l}\text { (独法) 水産総合センター水産工学研究所 } \\
\text { 水産土木工学部 部長 }\end{array}$ \\
\hline & 正会員 & 工博 & $\begin{array}{l}\text { (独法) 水産総合センター水産工学研究所 } \\
\text { 水産土木工学部 水産基盤グループ長 }\end{array}$ \\
\hline & & & $\begin{array}{l}\text { 水産庁漁港漁場整備部防災漁村課 } \\
\text { 課長補佐 }\end{array}$ \\
\hline & 正会 & 修(理) & $\begin{array}{l}\text { (株) アルファ水工コンサルタンッ } \\
\text { 東京本部 技師 }\end{array}$ \\
\hline & & & 国際気象海洋 (株) 次長 \\
\hline
\end{tabular}

表-1 概況調查地区一覧

\begin{tabular}{|c|c|}
\hline 県名 & 漁港名 \\
\hline 岩手県 & $\begin{array}{l}\text { 種市·久喜·太田名部·重茂·田老・宿・山田· } \\
\text { 吉里吉里・箱崎・再石·越喜来・野野前·六ヶ浦 }\end{array}$ \\
\hline 宮城県 & 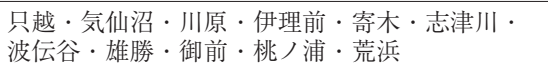 \\
\hline 福島県 & 釣師浜·松川浦·豊間 \\
\hline
\end{tabular}

手県 14 漁港, 宮城県 12 漁港, 福島県 3 漁港について, 現 地調査を行った。

現地調査の結果を調査表に取りまとめ, 整理した結果 を以下に示す.

・従来から指摘されている被災形態は全て発生.

・打継ぎ部など構造の弱点と考えられる箇所が被災.

・胸壁などでは本体工が剪断破壊している箇所がある。

・水門（丈夫な施設）の周辺の被災が多い.

・陸閘は引き波による被災が多い。

・津波が収斂したと考えられる箇所の被災が甚大.

・同じような地形でも漁港の向きにより被害の大小が あるなど被災状況に差がある。

\section{(2) 被災詳細調査}

\section{a）調査地区の選定}

概況調査の結果から，表-2に示す 10 漁港を構造, 被災 状況，地形特性などから選定した.

以下に選定理由を示す。

1）胸壁構造：大桘（被災大）・山田（被災大）

2）三面張り構造：宿（被災大)，樫内（被災無し）

3）同じ湾内：越喜来（被災大），崎浜（被災小）

4）外洋に面した漁港：田老（被災大），太田名部（被 災無し)

5）離岸堤等の被災：荒浜（被災大)，釣師浜（被災小） 
表-2 詳細調査地区一覧

\begin{tabular}{c|c|c|c|c}
\hline 県名 & 漁港名 & 被害規模 & 被災施設 & 津波高 \\
\hline 岩手県 & 太田名部 & 小 & なし & 9 \\
\cline { 2 - 5 } & 田老 & 中 & 防潮堤他 & 16 \\
\cline { 2 - 5 } & 樫内 & 不明 & なし & \\
\cline { 2 - 5 } & 宿 & 不明 & 防潮堤他 & $15 \sim 23$ \\
\cline { 2 - 5 } & 山田 & 大 & 防潮堤他 & 11 \\
\cline { 2 - 5 } & 大槌 & 不明 & 胸壁 & \\
\cline { 2 - 5 } & 崎浜 & 不明 & 防潮堤 & \\
\cline { 2 - 5 } & 越喜来 & 中 & 防潮堤・離岸堤他 & 18 \\
\hline 宮城県 & 荒浜 & 大 & 防潮堤・離岸堤他 & 11 \\
\hline 福島県 & 釣師浜 & 大 & 護岸・離岸堤他 & 12 \\
\hline
\end{tabular}

注）被害規模：大（被害額10億円以上）中（1億円以上） 小 (1億未満) 不明（調査時被害額不明）

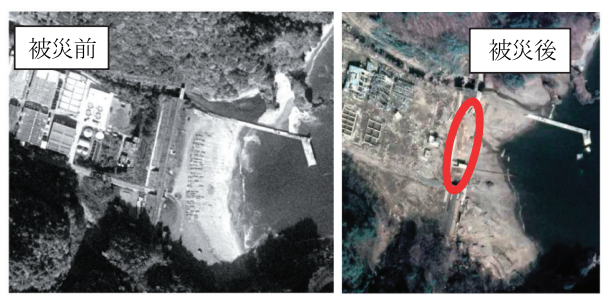

写真-1 被災前後の航空写真

\section{b) 調査方法}

詳細調査項目, 内容は以下の通りである.

1) 調査施設の概要

海岸台帳等により調査施設の諸元（延長，天端高， 構造形式など）把握.

2）航空写真による地形変化状況等の把握

海岸保全施設の被災実態，被災延長，施設・部材 の飛散等の状況について, 既存の航空写真および 模型飛行機による空撮及び測量調査等により把握.

3）海岸保全施設の破損状況

現地での目視調査により海岸保全施設の破損状況 を確認.

4）津波の浸水深, 遡上高, 浸水範囲の確認調査 既存の津波痕跡高調査結果に記載されている津波 の痕跡を確認.

5）コンクリート構造物の飛散状況および洗掘状況

2）および3）の調査結果をもとに，コンクリート

構造物の飛散状況および洗掘状況について把握.

以上の調査結果を取りまとめ, 被災状況に応じた分類 表を作成するとともに，海岸保全施設の損傷状況に差異 が生じた原因等について考察した。

\section{c) 調査事例 (宿漁港)}

調査事例として，宿漁港の調査結果を以下に示す.

写真-1に被災前と被災後の航空写真を示す.

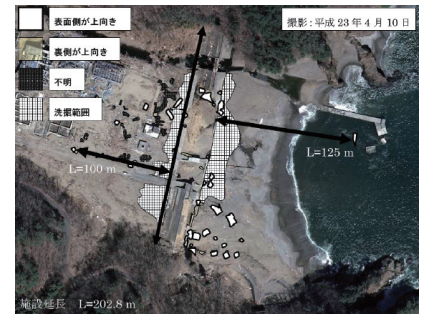

写真-2 構造物の被災状況

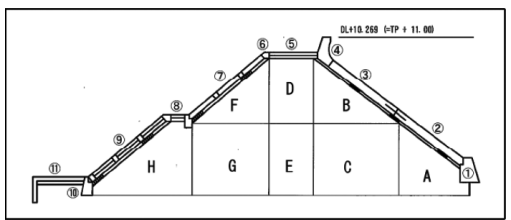

図-1 構造物の部位区分

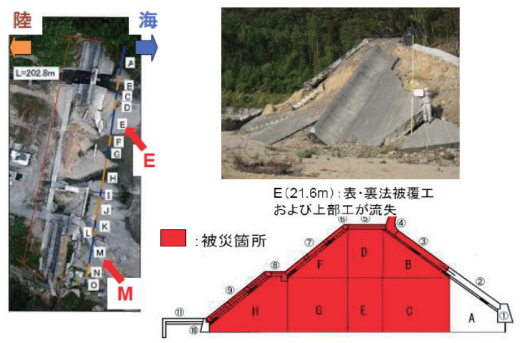

図-2 調査事例（1）

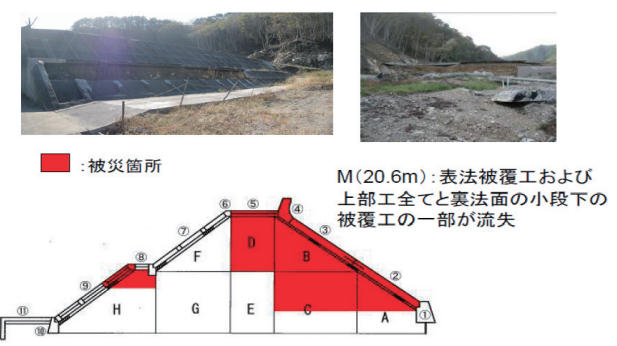

図-3 調查事例（2）

写真-1から三面張りの防潮堤が被災し, 背後の建物が 破壊されている様子がわかる.

写真-2に構造物の飛散状況および侵食範囲を示す.

三面張り被覆工が押し波・引き波により海側および陸 側に $100 \mathrm{~m}$ 以上飛散しており，堤体前面，背後が侵食さ れている状況がわかる。

海岸保全施設（三面張り構造）被災状況を把握するた めに15断面に分割し，各断面における部位の被災状況を 調査した。被災部位の区分を図-1に示す。

宿漁港における部位の被災調査結果を図-2，3に示す。

図-2,3から，同一施設においても被災状況が異なり，E 地点では表法面の一部を除き全壊しているが，M地点で は表法面と天端および子段が被災していることがわかる. 


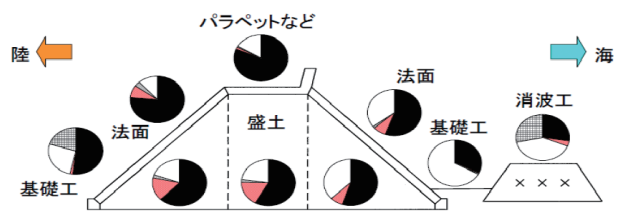

図-4 調査結果 (三面張り)

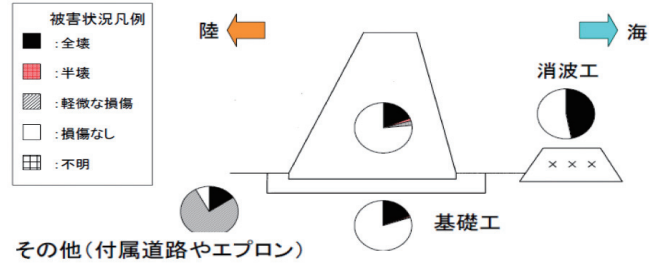

図-5 調查結果（胸壁）
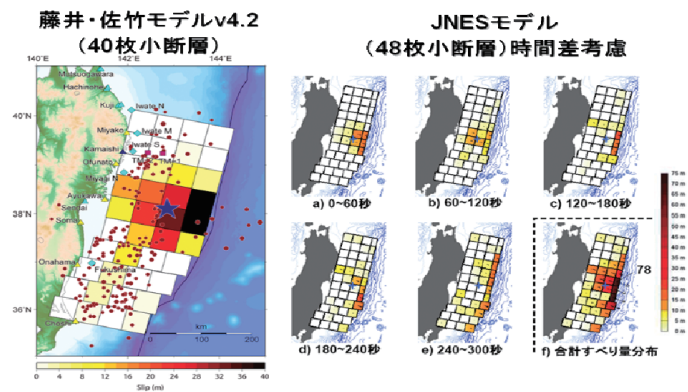

図-6＼cjkstart波源モデルの概要

\section{d）調査結果}

詳細調査を実施した 10 漁港海岸のうち, 三面張り構造 の調査結果を図-4に，胸壁構造の調査結果を図-5に示す。

図-4より，3面張り堤防では消波工の被災は少なく， 基礎工の被災は前面より背後が多いこと，パラペット等 の天端部，裏法面などの被災が多いことがわかる．この ことから, 越流により裏法面・法尻などが被災し, 堤全 体の被災に至るものと考えられる。

図-5より，胸壁は3面張り堤防に比べて被災率が小さ いが，全壊率が高いことがわかる，ただし，全壊した胸 壁でも堤体自体が破壊されることは少なく, 前後の地盤 の浸食により，転倒・滑動しているケースが多い.

\section{3. 波源モデルの検証}

\section{（1）波源モデル}

図-6に示す2つの波源モデルについて，再現性の検証 を行った.

\section{(2) 格子間隔}

検証に用いた非線形長波による数值計算の格子間隔は $1350 \mathrm{~m} \sim 50 \mathrm{~m}$ とした.

\section{(3) 検証結果}

各波源モデルについて，K，Kを用いた津波解析モデル
表-3 $K, \kappa に よ る$ 再現性検証結果

\begin{tabular}{c|c|c|c|c}
\hline & \multicolumn{2}{|c|}{ 藤井・佐竹V42 } & \multicolumn{2}{|c}{ JNES } \\
\hline すべり量倍率 & $K$ & $\kappa$ & $K$ & $\kappa$ \\
\hline 1.0 & 0.950 & 1.308 & 0.95 & 1.300 \\
\hline
\end{tabular}
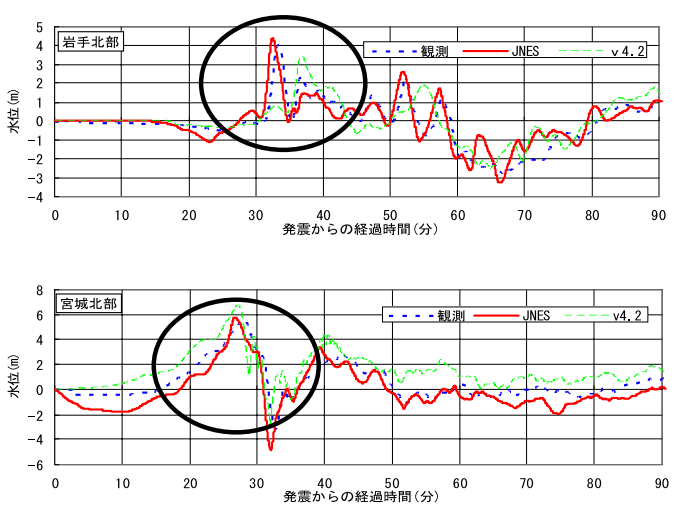

図-7 GPS 波浪計の観測結果との比較

適合度検証法（Aida, 1978）により，再現性の検討を行 うとともに，GPS 波浪計により観測された津波の波形と の整合性の比較を行った．再現対象とした津波痕跡高は, 東北地方太平洋沖地震津波合同調査グループ（TTJT）に おいて収集された青森県から千葉県までの沿岸での痕跡 高を 38 点抽出した.

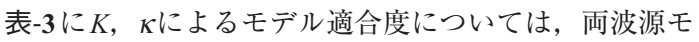
デルの計算結果に差異は見られなかった。

図-7にGPS 波浪計の観測波と各波源モデルの計算結果 を示す.

図-7より, 岩手北部において, 藤井・佐竹モデル (Fujiiら,2011) はピーク開始時間のずれと宮城県中部に おいて, 水位のずれが見られる.JNESモデル（独法原子 力安全基盤機構, 2011）は藤井・佐竹モデルに比較して, 津波観測波形の整合性に優れていたことから，JNESモデ ルにより以下の検討を行った。

\section{4. 被災メカニズムの検討}

\section{（1）再現性検証}

再現計算では, 波源モデルにより計算される地殼変 動量に空間的に一様な係数 (倍率) を乗じ, 対象地域 周辺で測定された津波の痕跡高と計算による津波高を 整合させることで，波源モデルのキャリブレーション を行った。

再現対象とした津波痕跡高は, 東北地方太平洋沖地震 津波合同調査グループ（TTJT）により統合された太平洋 沿岸域における津波痕跡高のデータベースに収納されて いる痕跡高である. 
波源モデルのキャリブレーションは，津波遡上計算 結果より対象計算格子における最高津波高を抽出し, 測定された痕跡高と比較するにより，最適なすべり量 倍率を決定した。表-4に示す波源モデルのキャリブレ ーション結果によると, すべり量倍率は, $0.9 〜 1.0$ 倍と なっている.

\section{(2) 再現計算検証事例}

ここでは, 越喜来・崎浜漁港における検証事例を示す.

図-8に示す津波の痕跡高と津波遡上計算結果より，最 高津波高を抽出し, 観測された痕跡高と比較することに より最適なすべり量倍率を決定した。

現実の津波来襲時には，堤防や防波堤等の施設の倒壊 が生じたことも考慮し, 以下の6ケースについて計算津 波高と実測痕跡高との比較を行った。ここで，構造物の 被災を考慮したケースとは，被災構造物に対応する構造 物デー夕を除去し, 加えて被災構造物と対応する地形デ ー夕を平滑化したものである.

計算ケース すべり量倍率：0.8，0.9，1.0

構造物：被災無し（被災前），被災考慮（被災無し）

計算津波高と実際の痕跡高との比較を図-9に示す.

\begin{tabular}{c|c} 
表-4 波源モデルのキャリブレーション結果 \\
\hline 漁港名 & 最適倍率 \\
\hline 太田名部 & 0.9 \\
\hline 田老 & 1.0 \\
\hline 宿 & 0.9 \\
\hline 越喜来 & 0.9 \\
\hline 崎浜 & 0.9 \\
\hline 荒浜 & 0.9 \\
\hline 釣師浜 & 0.9
\end{tabular}

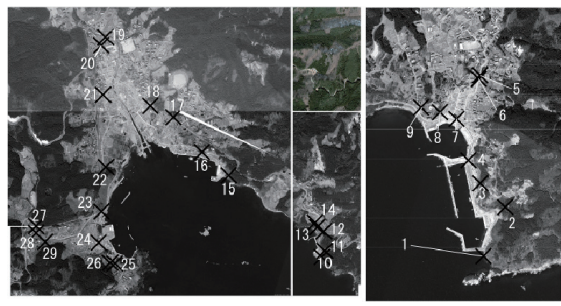

図-8 越喜来・崎浜漁港痕跡痕

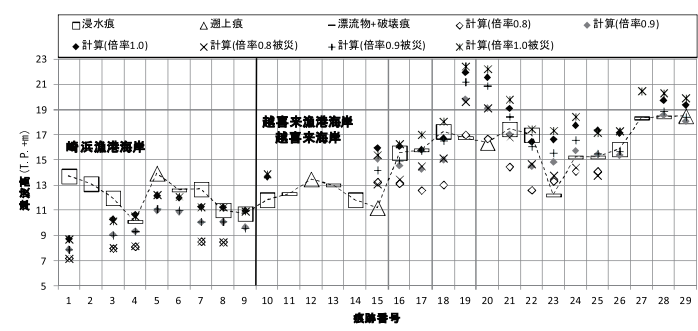

図-9 越喜来・崎浜漁港の検証計算結果

\section{（3）被災メカニズムの検討}

再現計算をもとに，被災規模の大きい代表的な漁港 （越喜来・崎浜, 宿, 他 2 漁港）について被災メカニズム の検討を行った．検討結果の代表的な例として，越喜来 漁港，崎浜漁港および宿漁港における検討結果を以下に 示す.

越喜来漁港および崎浜漁港の防潮堤について, 詳細調 査結果による被災程度と再現計算結果による水位および 流速の関係について検討を行った。

図-10に越喜来・崎浜漁港の被災状況および断面抽出 点を, 図-11に各断面における最大水位及び最大流速を 示す.

図-10,11より，詳細調査結果による被災程度と再現計 算結果による津波外力の比較を示す。

詳細調査結果による各地点の被災状況は，以下の通り である。

・抽出点 $3 \sim 6$ においては堤体の流出および地盤の洗 掘が生じており，被災程度が大きい。

·抽出点 $2,7,9 ， 10$ において被災は生じているが, 堤体が残存していること, 抽出点 $3 \sim 6$ に比べて地 盤の洗掘量が小さいことから, 被災程度は中程度で ある.

・その他の地点においては，被災は比較的軽微である。 被災程度が大きい箇所では，流速が $3 \mathrm{~m} / \mathrm{s}$ 以上となっ ており，流速が減少するとともに被災程度も小さくなっ

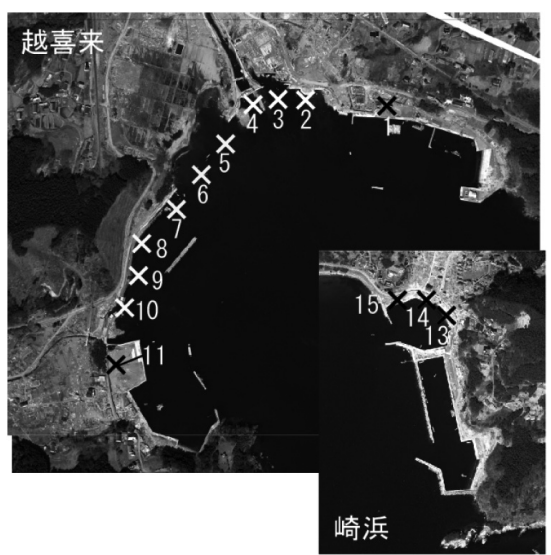

図-10 越喜来・崎浜断面抽出点

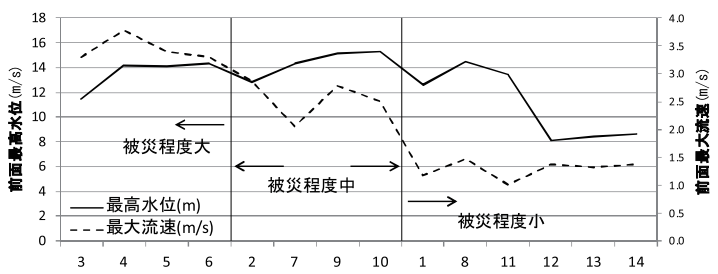

図-11 最高水位・最大流速の沿岸分布と被災程度 
ている.これは, 防潮堤に対する津波の来襲方向に起因 しているものと考えられ, 最大流速によって被災程度を 概ね評価できる。また，被害のほとんど生じなかった崎 浜漁港（抽出点 $12 \sim 14$ ）では, 津波水位も低くなって いることから，津波水位による影響もあるものと考えら れる。

宿漁港や他の漁港においても, 概ね越喜来漁港と同等 に被災程度等と津波外力（水位や流速）との対応関係が 見られた。

断面における被災部位の差異を検討するため，宿漁港 において数值波動水槽（財 沿岸技術研究センター, 2008） による計算を行った。その結果を図-12,13に示す.

図-12,13より毫法面の小段付近負圧が発生すること による吸い出し, 小段天端および裏法尻付近では圧力の 集中と大きな流速 $(10 \mathrm{~m} / \mathrm{s} \sim 13 \mathrm{~m} / \mathrm{s}$ 程度）が発生してい ることがわかる．宿漁港の詳細調査による小段工の被災 や天端の被災および侵食などの被災状況と良く一致して いる.

以上の検討から，被災の発生箇所は，水位が高く流速 が早い箇所と考えられ，断面的には負圧の発生，裏法尻
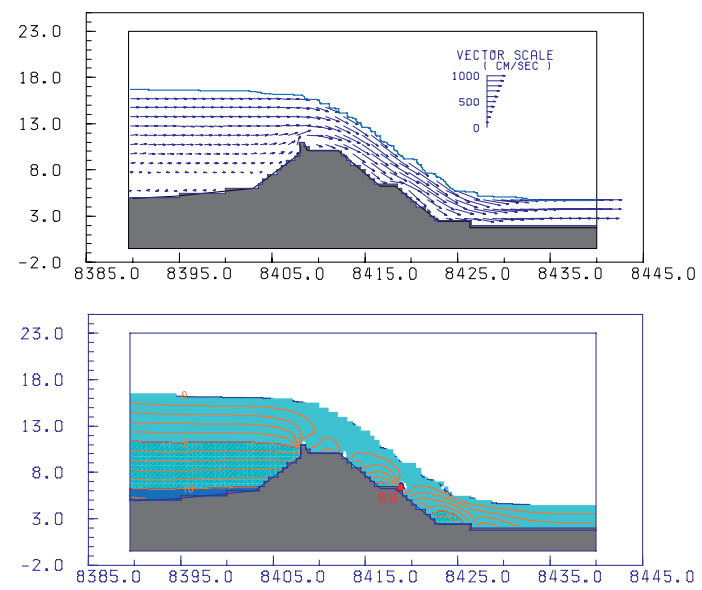

図-12 計算結果（上：流速，下：圧力分布）

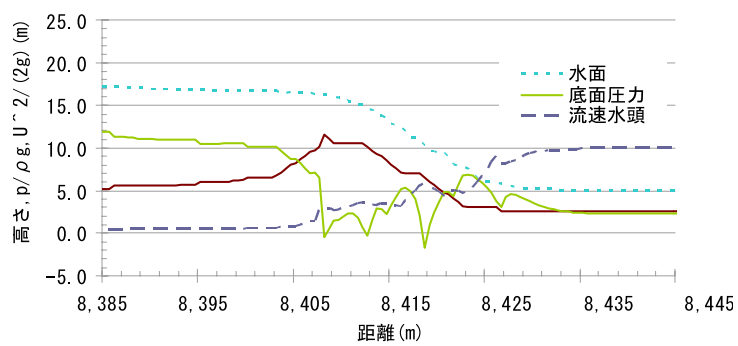

図-13 防潮堤周辺の底面圧力・流速分布
付近の圧力増大, 流速の増加傾向がある箇所であること がわかった。

\section{5. おわりに}

2011 年3月 11 日に発生した東北地方太平洋沖津波によ り，被害が発生した海岸保全施設の被災状況を詳細に調 査し, 非線形長波による津波シミュレーションおよび数 值波動水槽により被災メカニズムを検討した。

1）漁港海岸において海岸保全施設の詳細な調査を行い, 津波による構造別・部位別の被災状況を把握した。 そ の結果, 胸壁は三面張り堤防と比較して, 被災率は低 いが全壊率は高いこと, 三面張り構造は天端から背後 の被災が多いことが判明した。

2）波源モデルについては，藤井・佐竹Ver4.2 と JNES モ デルを比較した， $K, \kappa$, によモデル適合度検証法で は顕著な違いは確認できなかったが，GPS 波浪計によ る観測波形との位相などに着目した適合性からJNES モデルを採用した。

3）シミュレーションによる被災時の再現計算結果によ り, 越喜来漁港や宿漁港の海岸保全施設の被災箇所は, 被災していない箇所と比較して, 水位が高く流速が早 い箇所であり，断面的には裏法小段部で負圧の発生， 裏法尻付近の圧力増大, 流速の増加傾向があることが わかった，すなわち，漁港海岸の海岸保全施設の被災 は, 水位, 流速, 圧力等の作用した外力の違いによっ て生じていたことが明らかとなった。

謝辞：最後に, 本調査は水産庁発注による「平成 23 年度 海岸保全施設設計条件等緊急調査」の一部をとりまとめ たものであり, 本調査研究をとりまとめるのにあたり, 有益なアドバイスをいただいた東北大学の首藤伸夫名誉 教授, 防衛大学校の藤間功司教授, 秋田大学の松冨英夫 教授ならびに水産庁関係各位に謝意を表します。

\section{参 考 文 献}

(独法) 原子力安全基盤機構 耐震安全部（2011）：原子力事業 者が実施した平成 23 年東北太平洋沖地震により発生した 津波の再現計算結果等に係るクロスチェック解析, 地震・ 津波 3-4.

（財）沿岸技術研究センター（2008）：CASDMAS-SURF 実務 計算事例集，沿岸技術ライブラリーNo.30.

Aida, I. (1978) : Reliability of a tsunami source and model derived from fault parameters. J. Phys. Earth, 26, pp.57-73.

Fujii ,Y., K. Satake, S. Sakai, M. Shinohara, and T. Kanazawa. (2011) : Tsunami source of the 2011 off the Pacific coast of Tohoku Earthquake, Earth Planets Space, 63, pp.815-820.

東北地方太平洋沖地震津波合同調査グループ, 東北地方太平洋 沖地震津波情報共有サイト, http://www.coastal.jp/ttjt/ 